\title{
Environmental and Nutritional Health Awareness on Musca domestica as a Carrier of Parasites in Jos Metropolis, Plateau State-Nigeria
}

\author{
Agbalaka I Priscilla ${ }^{1}$, Obeta M Uchejeso ${ }^{2 *}$, Ejinaka R Obiora ${ }^{1}$, Dajok D \\ Godfrey $^{3}$ and Jwanse I Rinpan ${ }^{4}$ \\ ${ }^{1}$ Department of Parasitology, Federal School of Medical Laboratory Science, \\ Jos, Nigeria \\ ${ }^{2}$ Department of Chemical Pathology, Federal School of Medical Laboratory Science, Jos, \\ Nigeria \\ ${ }^{3}$ Department of Bacteriology, Federal School of Medical Laboratory Science, Jos, Nigeria \\ ${ }^{4}$ Health and Development Support Programme (HANDS), Jos, Nigeria \\ *Corresponding Author: Obeta M. Uchejeso, Department of Chemical Pathology, \\ Federal School of Medical Laboratory Science, Jos, Nigeria.
}

Received: January 30, 2020

Published: February 06, 2020

(C) All rights are reserved by Obeta $\mathbf{M}$

Uchejeso., et al.

DOI: $10.31080 /$ ASNH.2020.04.0636

\begin{abstract}
Background: Musca domestica (houseflies) from the environment may be contaminated with various parasites of public health significance. Jos has numerous flies amidst various hips of refuse in various areas of the metropolis that could overwhelm community health professionals.

Objectives: The study was aimed to create awareness among Jos residents and identify parasites found with houseflies in Jos.

Materials and Methods: An experimental study to detect parasites/Awareness Questionnaire involving 400 houseflies and 100 volunteers from 4 sites in Jos followed by statistical analysis.

Result: Parasitic infection of houseflies within study area in relation to socio- demographics characteristics of respondents, shows that there was no significant difference at ( $p>0.05)$. Based on gender, male had infection of $29(42.6 \%)$ while female had $10(31.3 \%)$. Age of 10-20 years had 4(30.8\%), 21-30 years 13(33.3\%), 31 years and above 22(45.8\%). Educational levels shows: No formal education 2(50.0\%), primary level 7(43.8\%), secondary level 10(34.5\%), and tertiary 20(39.2\%). Yes response for Knowledge on the Housefly borne diseases (92\%) Knowledge of role in infection (93\%) and Knowledge of transmission of typhoid, Dysentery, cholera (86\%) but the prevalence of parasites are more on those that are not knowledgeable. There was significant difference in housefly infestation with parasite based on locations at $(\mathrm{p}<0.05)$ showing Terminus market $19(76.0 \%)$ and Federal school as the least $4(16.0 \%)$. Conclusion: The residents of Jos metropolis are knowledgeable on the public environmental health effects of Musca domestica and there is a need for all community health practitioners to partner with government and non-governmental bodies to reduce parasite transport and diseases through Musca domestica.

Keywords: Musca domestica; Parasites; Environmental Health Awareness; Jos
\end{abstract}

\section{Introduction}

The common housefly, Musca domestica is recognized as transport hosts to human for a variety of parasites in addition to viral and bacterial pathogens of public health importance through its vomits or excreta or mechanically through its appendages [1]. Houseflies (Musca domestica) are the most common of all domestic flies, accounting about $90 \%$ of all flies in human habitation all over the world [2]. There are about 170 genera and 4200 species in the family Muscidae, Some of which are medically important including the housefly, Musca domestica [3]. Insects are classified as vectors when they transmits pathogenic organisms from humans (or animals) to humans. Houseflies (Musca domestica) are known to be transport hosts of a variety of pathogens (over 130 pathogens) of public health importance $[4,5]$. Refuse houseflies have been incriminated in transmission of helminth eggs, that is, Ascaris lumbricoides, Trichuris trichuria, Enterobius vermicularis, Toxocara canis, Strongyloides stercoralis, Protozoan cyst, and trophozoites such as Entamoeba histolytical, Giardia species, Trichomonas species, Taenia species, Hymenolepsis species. Also, Eimeriatenella, the coccidian parasite of poultry can be mechanically transmitted by houseflies (Mullen and Durden 2002). Houseflies are found mostly during the day and like warm places showing a preference for direct sunshine. Their filthy habits is seen in the way they defecate while they feed, thereby distributing germs [6]. Houseflies as mechanical vectors pick up the infection agent on the outside of its body and transmit it in a passive manner. Flies can carry human pathogens on the sponging mouth part, on body and leg hairs (setae) or on the sticky pads of the feet (tarsi) (Tarnang 2005). Protozoan parasite can pass through the fly gastro intestinal tract without alteration of their infectivity and can be subsequently deposited on visited 
surface in faecal spots (Othman 2008). Houseflies are recognized as carries of communicable disease. They collect pathogens on their body parts when female lay eggs on the decomposing organic matters such as the droppings domesticated birds, cows and pigs faeces, rubbish dumps, corpses and foods [7]. Diseases carried by houseflies include typhoid, cholera and dysentery. Other diseases carried by houseflies includes salmonella, anthrax and tuberculosis. They have also been known to transmit the eggs of parasitic worms. They constitute serious public nuisance through their dirty breeding environment, feeding mechanisms and indiscriminate travel, thus making them efficient vectors of human enteric protozoan parasite [8]. Housefly is a cosmopolitan pest of farm, home and its synanthropic to humans [9]. Houseflies are mostly active and live longest temperature between $10-26.5^{\circ} \mathrm{C}$, but are inactive at low temperature below $7.2^{\circ} \mathrm{C}$ and could die in extreme temperature $0^{\circ} \mathrm{C}$ or above $44.4^{\circ} \mathrm{C}$. The ecological monitoring of flight range showed that individual flies can travel as far as 20 miles, although vast majority movement is oriented towards unsanitary sites. Houseflies ecological movement are drawn majorly to high densities of human waste and garbage which constitute their food which they in as fluids and tiny materials and coincidentally as noted by these feeding sites are the breeding site of houseflies which have been reported to include horse manure, human excreta, cow manure, fermenting vegetables and fruits garbage and kitchen wastes and commonly exposed human foods [10]. At the course of their breeding, the females have been reported to be able to lay up to 500 eggs. Due to houseflies indiscriminate mode of feeding, they have been described as potential vectors of more than 100 serious pathogens which includes enteric protozoan cyst and trophozoites like Entaemoba histolytica, Cryptosporidium parvum and Entameoba coli, Sacrocystic species, Toxoplasma gondii, Isospora species, Giardia species, Trichomonas species and Diphyl- lobothrium species. These pathogens have been reported to cause serious health implication. Excessive fly populations are not only an irritant to form workers, but when they are nearby human habitations, a public health problem could occur (Mullen and Durden 2002).

\section{Materials and Methods}

Consent were obtained from the respondent and questionnaires were tested on 25 volunteers each from the four selected sites: Federal school of medical laboratory science, Jos premises, Abattoir, Bukuru old-park and Terminus market $(25 \times 4=100)$. A total of One hundred (100) Houseflies were randomly collected from the four selected sites each $(100 \times 4=400)$ mentioned above. The houseflies were obtained from the selected sites with aid of capturing fly trap (box) and transported to the Parasitology/Entomology Laboratory of Federal School of Medical Laboratory Science Jos for medical laboratory identification of parasites using the methods described by Ochei and Kalhatkah [11]. The analysis was done using SPSS 17.

\section{Results}

Table 1 below is Parasitic infection of houseflies within study area in relation to socio- demographics characteristics of respondents which shows that there was no significant difference in the parasite infestation of houseflies (Musca domestica) within study sites based on socio- demographics characteristics of respondents at ( $p>0.05)$. With respect to sex, male had infection of $29(42.6 \%)$ while female had $10(31.3 \%)$. With respect to age $10-20$ years had $4(30.8 \%), 21-30$ years $13(33.3 \%), 31$ years and above 22(45.8\%). With respect to level of education those with No formal education had $2(50.0 \%)$, primary level had $7(43.8 \%)$, and secondary level had $10(34.5 \%)$, while tertiary had $20(39.2 \%)$.

\begin{tabular}{|c|c|c|c|c|c|c|}
\hline Demographics & Variables & No. Examined & No. Infected (\%) & $\chi^{2}$ & Df & p-value \\
\hline \multirow[t]{3}{*}{ Sex } & Male & 68 & $29(42.6)$ & 1.188 & 1 & 0.380 \\
\hline & Female & 32 & $10(31.3)$ & & & \\
\hline & TOTAL & 100 & $39(39.0)$ & & & \\
\hline \multirow[t]{4}{*}{ Age (years) } & $10-20$ & 13 & $4(30.8)$ & 1.839 & 2 & 0.399 \\
\hline & $21-30$ & 39 & $13(33.3)$ & & & \\
\hline & 31 and above & 48 & $22(45.8)$ & & & \\
\hline & TOTAL & 100 & $39(39.0)$ & & & \\
\hline \multirow[t]{5}{*}{ Level of Education } & No formal education & 4 & $2(50.0)$ & 0.605 & 3 & 0.895 \\
\hline & Primary & 11 & $7(43.8)$ & & & \\
\hline & Secondary & 29 & $10(34.5)$ & & & \\
\hline & Tertiary & 51 & $20(39.2)$ & & & \\
\hline & TOTAL & 100 & $39(39.0)$ & & & \\
\hline
\end{tabular}

Table 1: Parasitic infection of houseflies within study area in relation to socio-demographics characteristics of respondents. Result is significant when $(\mathrm{p}<0.05)$.

Table 2 Parasitic infestation of houseflies with respect to study locations, shows that there was significant difference in housefly infestation with parasite based on locations at $(\mathrm{p}<0.05)$. Terminus market had housefly with the highest level of infection $19(76.0 \%)$ while Federal School had the least 4(16.0\%).
Table 3 Shows that the Yes response for Knowledge on the Housefly borne diseases (92\%) Knowledge of role in infection (93\%) and Knowledge of transmission of typhoid, Dysentery, cholera $(86 \%)$ however, in prevalence of parasites among the "Yes" and "No", there is no significant difference in housefly infestation with respect to 


\begin{tabular}{|l|c|c|c|c|c|c|}
\hline & Variables & No. Examined & No. Infected (\%) & $\chi \mathbf{2}$ & Df & p-value \\
\hline \multirow{4}{*}{ Location } & Federal school & 25 & $4(16.0)$ & 22.872 & 3 & 0.001 \\
\cline { 2 - 7 } & Abattoir & 25 & $7(28.0)$ & & & \\
\cline { 2 - 7 } & Bukuru old park & 25 & $9(36.0)$ & & & \\
\cline { 2 - 7 } & Terminus market & 25 & $19(76.0)$ & & & \\
\cline { 2 - 7 } & TOTAL & 100 & $39(39.0)$ & & & \\
\hline
\end{tabular}

Table 2: Parasitic infestation of houseflies with respect to study locations. Result is significant when $(\mathrm{p}<0.05)$

\begin{tabular}{|c|c|c|c|c|c|c|}
\hline Knowledge & Response & Response No. as Examined & No. Infected (\%) & $\chi^{2}$ & Df & p-value \\
\hline \multirow[t]{3}{*}{ Heard of Housefly borne Disease } & Yes & 92 & $34(37.0)$ & 2.019 & 1 & 0.155 \\
\hline & No & 8 & $5(62.5)$ & & & \\
\hline & Total & 100 & $39(39.0)$ & & & \\
\hline \multirow[t]{3}{*}{ Knowledge of role in infection } & Yes & 93 & $38(40.9)$ & 1.932 & 1 & 0.164 \\
\hline & No & 7 & $1(14.3)$ & & & \\
\hline & Total & 100 & $39(39.0)$ & & & \\
\hline \multirow{3}{*}{$\begin{array}{l}\text { Knowledge of transmission of } \\
\text { typhoid, Dysentery, cholera }\end{array}$} & Yes & 86 & $33(38.4)$ & 0.102 & 1 & 0.750 \\
\hline & No & 14 & $6(42.9)$ & & & \\
\hline & Total & 100 & $39(39.0)$ & & & \\
\hline
\end{tabular}

Table 3: Parasitic infection of houseflies within study area in relation to knowledge of houseflies borne diseases respondents. Result is significant when $(\mathrm{p}<0.05)$.

knowledge of houseflies borne diseases respondents at ( $p>0.05)$. With respect to respondent to have ever heard of housefly borne disease. Those who said "Yes" infection rate was 34(37.0\%) while those who said "No" was 5(62.5\%). With respect to Knowledge of role of housefly in infection those who said "Yes" had 38(40.9\%) while those who said "No" had 1(14.3\%). With respect to respondents having Knowledge of housefly transmission of typhoid, dysentery, cholera, those who responded "Yes" had 33(38.4\%), while "No" was 6(42.9\%) Result is significant when ( $\mathrm{p}<0.05)$.
Table 4 Parasitic infection of houseflies within study area in relation to preventive measures taken by respondents, shows that there was no significant difference in housefly infection with parasite across all their preventive measures taken at $(\mathrm{p}>0.05)$ With respect to frequency of clearing vector dwelling sites, those clean daily there was an infection rate of $16(32.7 \%)$, those who clean weekly it was $19(48.7 \%)$ while those who clean monthly $4(33.3 \%)$. With respect to presence of a regular plan of cleaning housefly environment, those who said Yes was 31(38.8\%) while

\begin{tabular}{|c|c|c|c|c|c|c|}
\hline Prevention & Response & No. Examined & No. Infected (\%) & $x^{2}$ & Df & p-value \\
\hline \multirow{4}{*}{$\begin{array}{l}\text { Frequency of clearing vector } \\
\text { dwelling sites }\end{array}$} & Daily & 49 & $16(32.7)$ & 2.540 & 2 & 0.281 \\
\hline & Weekly & 39 & $19(48.7)$ & & & \\
\hline & Monthly & 12 & $4(33.3)$ & & & \\
\hline & Total & 100 & $39(39.0)$ & & & \\
\hline \multirow{3}{*}{$\begin{array}{l}\text { Presence of a regular plan of } \\
\text { Cleaning housefly environs }\end{array}$} & Yes & 80 & $31(38.8)$ & 0.011 & 1 & 0.918 \\
\hline & No & 20 & $8(40.0)$ & & & \\
\hline & Total & 100 & $39(39.0)$ & & & \\
\hline \multirow[t]{4}{*}{ Frequency of medical check up } & Not done & 34 & $10(29.4)$ & 2.008 & 2 & 0.366 \\
\hline & Biannually & 37 & $16(43.2)$ & & & \\
\hline & Quarterly & 29 & $13(44.8)$ & & & \\
\hline & Total & 100 & $39(39.0)$ & & & \\
\hline \multirow{3}{*}{$\begin{array}{l}\text { Knowledge that hand washing } \\
\text { reduces risk of infection }\end{array}$} & Yes & 55 & $20(36.4)$ & 0.357 & 1 & 0.550 \\
\hline & No & 45 & $19(42.2)$ & & & \\
\hline & Total & 100 & $39(39.0)$ & & & \\
\hline \multirow[t]{4}{*}{ Frequency of hand washing } & Once & 6 & $3(50.0)$ & 0.470 & 2 & 0.791 \\
\hline & Twice & 19 & $8(42.1)$ & & & \\
\hline & As needed & 75 & $28(37.3)$ & & & \\
\hline & Total & 100 & $39(39.0)$ & & & \\
\hline \multirow[t]{4}{*}{ Frequency of fumigation } & Weekly & 25 & $10(40.0)$ & 0.824 & 2 & 0.662 \\
\hline & Monthly & 19 & $9(47.0)$ & & & \\
\hline & As needed & 56 & $20(35.7)$ & & & \\
\hline & Total & 100 & $39(39.0)$ & & & \\
\hline
\end{tabular}

Table 4: Parasitic infection of houseflies within study area in relation to preventive measures taken by respondents. Result is significant when $(\mathrm{p}<0.05)$ 
No was $8(40.0 \%)$. With respect to Frequency of medical checkup those who have never done was $10(29.4 \%)$, those who do it biannually was $16(43.2 \%)$ while quarterly was $13(44.8 \%)$. With respect to knowledge that hand washing reduces risk of infection, those who said Yes was 20(36.4\%) while those who said No 19(42.2\%). With respect to Frequency of hand washing, those who wash once $3(50.0 \%)$, twice was $3(50.0 \%)$ while those who wash as needed was $28(37.3 \%)$. With respect to Frequency of fumigation, those who fumigate weekly there was an infestation rate of $10(40.0 \%)$, those who fumigate Weekly it was $10(40.0 \%)$ and monthly was $9(47.0 \%)$ while when as needed it was $20(35.7 \%)$.
Table 5 Parasitic infestation of houseflies within study area in relation to physical preventive measures taken by respondents to prevent breeding, shows that there was no significant difference in housefly infestation in all the above preventive measures taken at ( $p>0.05)$. With respect to Garbage collection, those who collect once a Week had infestation rate of $14(40.0 \%)$ while those who collect Twice a week was $25(38.5 \%)$. With respect to respondents inviting sanitary officer, those who said Yes had infestation rate of $14(43.8 \%)$ while those who said No was $25(36.8 \%)$. With respect to frequency of Invitation of sanitary officer those who do this monthly was 22(37.9\%), quarterly was $14(38.9 \%)$ and Biannually was $3(50.0 \%)$.

\begin{tabular}{|l|c|c|c|c|c|c|}
\hline \multicolumn{1}{|c|}{ Prevention } & Response & No. Examined & No. Infected (\%) & $\chi \mathbf{2}$ & Df & p-value \\
\hline \multirow{4}{*}{ Garbage collection } & Once a Week & 35 & $14(40.0)$ & 0.023 & 1 & 0.880 \\
\hline & Twice a week & 65 & $25(38.5)$ & & & \\
& Total & 100 & $39(39.0)$ & & & \\
\hline & & & & & \\
\hline \multirow{3}{*}{ Sanitary officer Invitation } & Yes & 32 & $14(43.8)$ & 0.446 & 1 & 0.504 \\
\hline & No & 68 & $25(36.8)$ & & & \\
\cline { 2 - 7 } & Total & 100 & $39(39.0)$ & & & \\
\hline \multirow{3}{*}{ If yes how often } & & & & & & \\
\cline { 2 - 7 } & Monthly & 58 & $22(37.9)$ & 0.333 & 2 & 0.847 \\
\hline & Quarterly & 36 & $14(38.9)$ & & & \\
\cline { 2 - 7 } & Biannually & 6 & $3(50.0)$ & & & \\
\cline { 2 - 7 } & Total & 100 & $39(39.0)$ & & & \\
\hline
\end{tabular}

Table 5: Parasitic infestation of houseflies within study area in relation to physical preventive measures taken by respondents to prevent breeding.

Result is significant when $(\mathrm{p}<0.05)$.

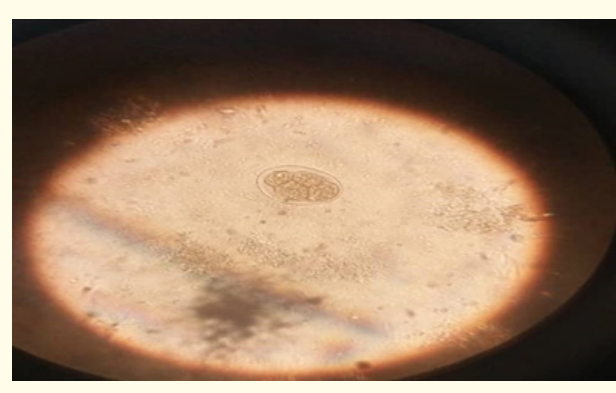

Figure 1: Ova of Hookworm

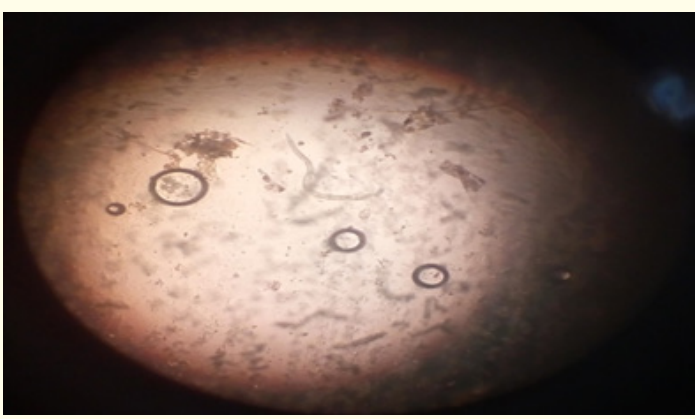

Figure 2: Strongyloides Stercoralis.

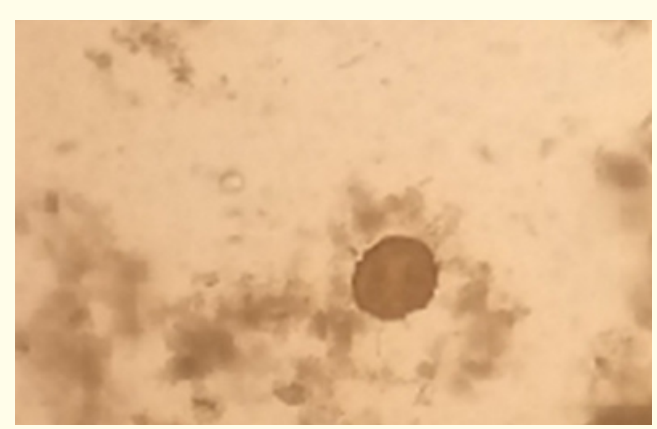

Figure 3: Ascaris lumbricoides ova.

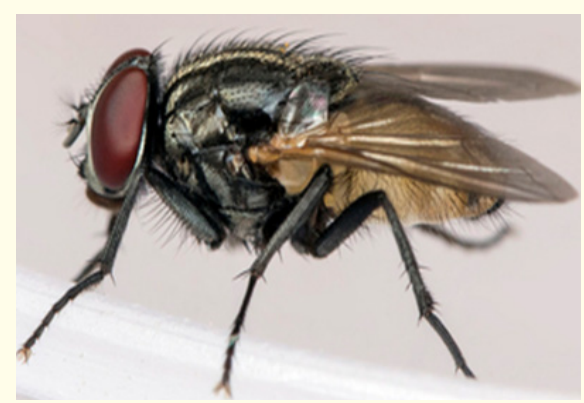

Figure 4: Musca domestica. 


\section{Discussion}

From Table 1, there was no significant difference in the parasite infestation of houseflies (Musca domestica) within study sites based on socio- demographics characteristics of respondents. With respect to sex, male had infection of $29(42.6 \%)$ while female had $10(31.3 \%)$. With respect to age 10-20 years had $4(30.8 \%), 21-30$ years $13(33.3 \%), 31$ years and above $22(45.8 \%)$. With respect to level of education those with No formal education had 2(50.0\%), primary level had $7(43.8 \%)$, and secondary level had $10(34.5 \%)$, while tertiary had $20(39.2 \%)$. The study showed that Musca domestica is a carrier of parasites and in agreement with Graczyk., et al. [12].

Looking at the sites of houseflies collections: Federal school of medical laboratory science, Jos premises, Abattoir, Bukuru oldpark and Terminus market as seen in table 2 , there was significant difference in housefly infestation with parasite based on locations. Terminus market had housefly with the highest level of infection $19(76.0 \%)$ while federal school had the least $4(16.0 \%)$. Clearly speaking, the terminus market lacks adequate toilet facilities and waste management system since the bombing of terminus market with high density population of people unlike Federal school environment with few people added to the fact that is a health training institution. This agrees with Khamesipour., et al. [4] that put it that density and characteristics of the pathogens carried by house flies depend on the area of vector collection.

The table 3, shows that there is no significant difference in housefly infestation with respect to knowledge of houseflies borne diseases according to the respondents. Khan., et al. [13], shows in their study in Punjab, Pakistan that respondents did not have sufficient knowledge on problems associated with house flies despite the fact of being very common pest in urban and rural areas. The respondents in Jos metropolis are relatively aware of that the housefly can transmit parasites or infections.

While some try good preventive and sanitary measures as shown in table 5, some with their knowledge and awareness still do not want to adopt a change. This relate with Koenraadt., et al. [14] when they opined that having a good knowledge about a particular subject does not necessarily lead to practice, due to difficult attitude to change in behaviour.

\section{Conclusion}

This study has shown that majority of Jos residents are aware of the public health importance of the Musca domestica, of which there is high prevalence of parasites among those that are not well informed about the public health matters raised in this work.

The residents of Jos metropolis are knowledgeable on the public environmental health effect of Musca domestica in Jos and there is a need for all community health practitioners to partner with government and non-governmental bodies to reduce parasite burden, transport and diseases especially in the Terminus, Bukuru Park, Abattoir and Federal School in that order.
Based on findings of the researcher, the following tips are recommended;

- That effort should tend towards sensitization of the public on the potential dangers posed by filth flies. Hence, the need for improved personal hygiene and environmental sanitation and adequate cooking of food (vegetables), which will reduce the tendency of spreading diseases by the flies [15-20].

- That there is need for Government to ensure the provision of adequate and effective health care systems and also enlightenment campaign by Government and Non- Governmental Organization (NGOs) to educate the general public on the significant role of Musca domestica as mechanical vector of diseases that could contaminate food.

- To educate and encourage the people to visit hospitals for treatment of any disease/infection.

\section{Acknowledgement}

The researchers acknowledge the Management, Medical Laboratory Scientists, Staff and students of Federal school of Medical Laboratory Technology, Jos for assisting in various categories during the research.

\section{Financial Competing Interest}

There is no financial competing interest in the study.

\section{Bibliography}

1. Adenusi AA and TO Adewoga. "Studies on the potential and public Health Importance of non-biting synanthropic flies in the mechanical transmission of human enterohelminths". Transactions of the Royal Society of Tropical Medicine and Hygiene 107 (2013): 812-518.

2. Nmorsi OPG., et al. "Detection of some Gastrointestinal parasite from four synanthropic flies in Ekpoma, Nigeria". Journal of Vector Borne disease 43 (2006): 136-139.

3. Service MWA. "Guide to Medical Entomology". The Macmillian press ltd Hongkong (2004): 102-105.

4. Khamesipour F., et al. "A systematic review of human pathogens carried by the housefly (Musca domestica L.)". BMC Public Health 18 (2018): 1049.

5. Akinbode OA., et al. "Public heath importance of market meat exposed to refuse flies and air borne micro-organisms". The International Journal of Zoonoses 11 (2009): 111-114.

6. Oghale 00., et al. "Parasite load on Muscadomestica (Diptheria: Muscidae) from different synanthropic environment in Umuahia Metropolis". Journal of Public Health Epidemiology 5 (2013): 309-312.

7. Mike S. "Medical entomology for students". Cambridge University Press, New York. Fifth edition. EENY. 48 (2014): 139-151. 
8. Graczky TF., et al. "Mechanical transmission of human protozoan parasites by insects". Clinical Microbiology Reviews 18.1 (2015): 128-132.

9. Sanchez Arroyo H and Capinera JL. "Housefly: University of Florida/IFAS featured creatures". Publication; EENY.48 (2015).

10. Lam K., et al. "Bacteria on housefly eggs. Musca domestica, suppress fungal growth in chicken manure through nutrient depletion or antifungal metabolites". Naturwissenchaften 96 (2009): 1127-132.

11. Ochie J and Kalhatkah A. Introduction to Medical Laboratory Science, Theory and Practice: Tata McGraw-Hill publishing company limited (2008): 111-128.

12. Graczyk TK., et al. "House flies (musca domestica) as transport hosts of cryptosporidium parvum". The American Journal of Tropical Medicine and Hygiene 61 (1999): 500-504.

13. Khan Hafiz Azhar Ali., et al. "A cross sectional survey of knowledge, attitude and practices related to house flies among dairy farmers in Punjab, Pakistan". Journal of Ethnobiology and Ethnomedicine 9 (2013): 18.

14. Koenraadt CJ., et al. "Dengue knowledge and practices and their impact on Aedes aegypti populations in Kamphaeng Phet, Thailand". The American Journal of Tropical Medicine and Hygiene 74 (2006): 692-700.

15. Agbalaka PI., et al. "Prevalence of Parasites of Public Health Significance in Vegetables Sold in Jos Metropolis, Plateau State, Nigeria". American Journal of Public Health Research 7.2 (2019): 48-57.

16. Arora DR and Brij BA. Medical parasitology, third Edition. CBS publishers and Distributors PVT. Ltd. New Delhi (2012): 21195.

17. Goulson D., et al. "Predicting fly population from weather and probable consequences of climate change". Journal of Applied Ecology 42 (2005): 795-800.

18. Howard JJ. "Nuisance flies around a landfill: patterns of abundance and distribution". Waste Management Research 19 (2011): 308-311.

19. Jordan EL and Verma PS. "Invertebrate zoology for B.Sc. (Hons)students of all Indian universities and also as per UGC Model Curriculum". S.C hand and Company Ltd. Ram Nagar, New Delhi-110055. (2010): 150-938.

20. Schmidth GD and Roberts LS. Foundations of Parasitology, 6th Edition. (McGraw Hill, New York 107 (2008): 586-592.

\section{Assets from publication with us}

- Prompt Acknowledgement after receiving the article

- Thorough Double blinded peer review

- Rapid Publication

- Issue of Publication Certificate

- High visibility of your Published work

Website: https://www.actascientific.com/

Submit Article: https://www.actascientific.com/submission.php Email us: editor@actascientific.com

Contact us: +919182824667 